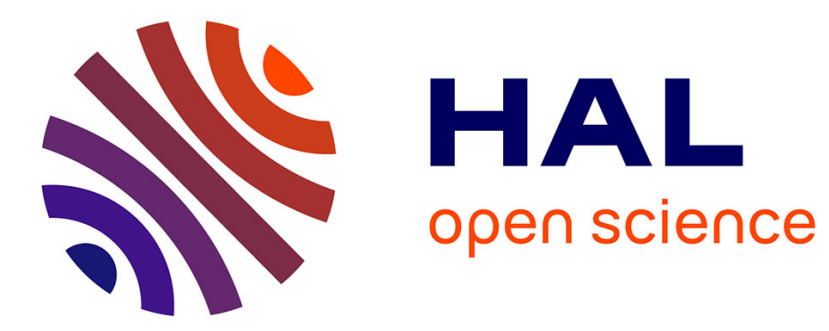

\title{
LASER INDUCED STRUCTURAL TRANSFORMATION IN AISI 430 STEEL
}

V. Teodorescu, L. Nistor, I. Apostol, I. Mihailescu, G. Daurelio, L. Cento, C. Esposito

\section{- To cite this version:}

V. Teodorescu, L. Nistor, I. Apostol, I. Mihailescu, G. Daurelio, et al.. LASER INDUCED STRUCTURAL TRANSFORMATION IN AISI 430 STEEL. Journal de Physique IV Proceedings, 1991, 01 (C7), pp.C7-43-C7-46. 10.1051/jp4:1991709 . jpa-00250746

\section{HAL Id: jpa-00250746 https://hal.science/jpa-00250746}

Submitted on 1 Jan 1991

HAL is a multi-disciplinary open access archive for the deposit and dissemination of scientific research documents, whether they are published or not. The documents may come from teaching and research institutions in France or abroad, or from public or private research centers.
L'archive ouverte pluridisciplinaire HAL, est destinée au dépôt et à la diffusion de documents scientifiques de niveau recherche, publiés ou non, émanant des établissements d'enseignement et de recherche français ou étrangers, des laboratoires publics ou privés. 


\title{
LASER INDUCED STRUCTURAL TRANSFORMATION IN AISI 430 STEEL
}

\author{
V.S. TEODORESCU, L.C. NISTOR, I.D. APOSTOL, I.N. MIHAILESCU, G. DAURELIO*, \\ L. CENTO* and C. ESPOSITO* \\ Institute of Atomic Physics, P.O. Box MG-6, R-76900 Bucharest, Romania \\ ${ }^{*}$ Centro Laser Bari, Via de Blasio 1, I-70123 Bari, Italy
}

\begin{abstract}
AISI 430 steel plates have been irradiated with $2 \mathrm{~kW} \mathrm{cW} \mathrm{CO}_{2}$ laser. Optical and transmission electron microscopy studies, revealed that the carbides existent before irradiation are dissolved in the irradiated zone where the steel was melted. After solidification, an uniform distribution of the $\boldsymbol{E}$ - carbide precipitates, 50 - $100 \mathrm{~nm}$ in size, appeared. The precipitation process was connected with the diffusion at dislocation core and with dislocation displacements and multiplications.
\end{abstract}

\section{INTRODUCTION}

The development of the laser-metal processing systems needs a large amount of experimental observations concerning the structural modifications which appear at laser irradiation. Experimental and theoretical works / $1,2 /$, have revealed the nonconventional aspects of the thermal treatment of the laser interaction with metals.

In this paper we proposed a structural analyse of the $2 \mathrm{~kW} \mathrm{cw}$ $\mathrm{CO}$ laser irradiation effects produced on the AISI 430 stainless steel with the composition : $0.12 \% \mathrm{C}, 1 \% \mathrm{Mn}, 1 \% \mathrm{Si}, 16-18 \% \mathrm{Cr}$, $0.03 \% \mathrm{~S}, 0.04 \% \mathrm{P}, \mathrm{w} . \mathrm{P}$., in order to study the laser welding process.

\section{EXPERIMENTAL}

$3 \mathrm{~mm}$ thick laminate steel plates have been irradiated in a geometry presented in fig.1. The laser radiation was focused in a $0.6 \mathrm{~mm}$ spot on the surface of the steel plates, which move perpendicularly to the laser beam direction, with a $2 \mathrm{~m} / \mathrm{min}$. speed. Metallographic observations have been performed after oxalic acid attack on transversal sections cutted from the irradiated samples (fig.2). The specimens for transmission electron microscopy (TEM) have been also cutted from the center of the irradiated zone. Electro-chemical thinning has been performed in a bath of $5 \%$ percloric acid in glacial acetic acid. For TEM,SEM and SAED observations a JEOL TEMSCAN - $200 \mathrm{CX}$ electron microscope has been used. 


\section{RESULTS AND COMMENTS}

The metallographic image in $\mathrm{fig.2}$, reveals three zones of interest in the steel sample : zone A - showing the initial state of the steel ; zone B - showing the central part of the irradiated region, situated in the bulk of the plate; zone $\mathrm{C}$ - showing the surface region of the irradiation track.

In the irradiated zone the steel was melted. Near the surface of the plate (zone $c$ ), the solidification is fast and the material undergoes a martensitic type transformation (fig.2). In the bulk (zone $B$ ), the process of the heat lost is lower and the final solidification structure was ferritic. The metallographic examination also revealed a nonuniform evolution of the heat front; the image in $\mathrm{fig} .2$ shows several isothermal like lines.

Before irradiation the steel has a ferritic structure, with lafge precipitates, 10 to $20 \mu \mathrm{m}$ in size, and a density of about $10 \% \mathrm{~cm}^{2}$. These precipitates have been identified in the electron diffraction (SAED) as $M_{6} C$ and $M_{23}{ }^{C} 6^{\cdot}$

During the melting process caused by the laser irradiation, these carbides are dissolved. The interface, between the region where the metal was melted and the remaining solid metal, is sharp on the melted side and extended at about $100 \mu \mathrm{m}$ in the other side ( $\mathrm{fig} 2,3)$. This interface can be assimilated with the heat affected zone (HAZ) in the conventional welding process, but in the laser case this region is less extended. As it is shown in $\mathrm{fig} .2$ and fig. 3 , in the HAZ region the most important structural aspect revealed is the gradual dissolution of the large carbides.

After solidification, region $B$ shows a dense and unifgrm distribution of small precipitates with a density of about $108 / \mathrm{cm}^{2}$, and dimensions of the order of $50-100 \mathrm{~nm}$ ( $\mathrm{fig.4}$ ).

The $100 \mathrm{~nm}$ precipitates are mature and were identified by electron diffraction as $\varepsilon$ - carbide $\left(M_{2} C\right)$, more probable $\mathrm{Cr}_{2} \mathrm{C}$ ( $\left.\mathrm{fig} .5\right)$.

The smaller precipitates ( $\mathrm{f}$. .6 ), are in the initial state of formation. They appear around the dislocation lines and in the TEM image look like dislocation tangles. As they are small, the selected area electron diffraction (SAED) cannot reveal consistent structural informations.

These observations lead to the conclusion that in the zone $B$, the heat lost rate, after solidification, is too low for an martensitic transformation, like in zone $C$, but also too high to permit the precipitation of mature carbides. In this case only a fast diffusion mechanism can work, which takes place along the dislocation lines. An approximate calculation shows that only $1 \%$ of the carbon atoms, disponible in the melted zone B, are precipitated in the small $\mathcal{E}$ - carbides, the rest of it remained in the solid solution. The isothermal like lines in the zone $B(f i g .2)$ is probable conected with the precipitation process, which give a singularity in the thermal time constant at $670 \mathrm{C} / 1 /$.

A second important aspect involved is the dislocation moving and multiplication which result from the fact that the central zone $B$ is strongly decompressed. This decompression hapend because the surface solidification (zone C) is more rapid, compared to bulk melted metal (zone $B$ ), which remains to fill a too big volume. 
So, after solidification, we expect in zone $B$ a large concentration of vacancies and large strains too. The presence of vacancies enhances the dif fusion processes while the strains are partially relaxed by dislocation displacements and multiplications.

\section{REFERENCES}

/1/ DAURELIO, G, CENTO,L, ESPOSITO,C Scientific Raport. Centro Laser Bari - 1982

/2/ URSU, I, MIHAILESCU, I, N, PROKHOROV, A, M, KONOV,,$I$ "Laser Heating of Metals "Adam Hilger. Ltd. (Bristol, N.Y., Philadelphia) 1990.

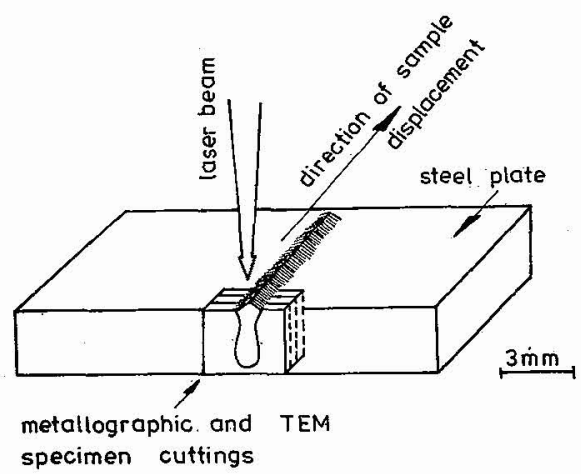

Fig. 1 Irradiation and investigation geometry of the steel sample.

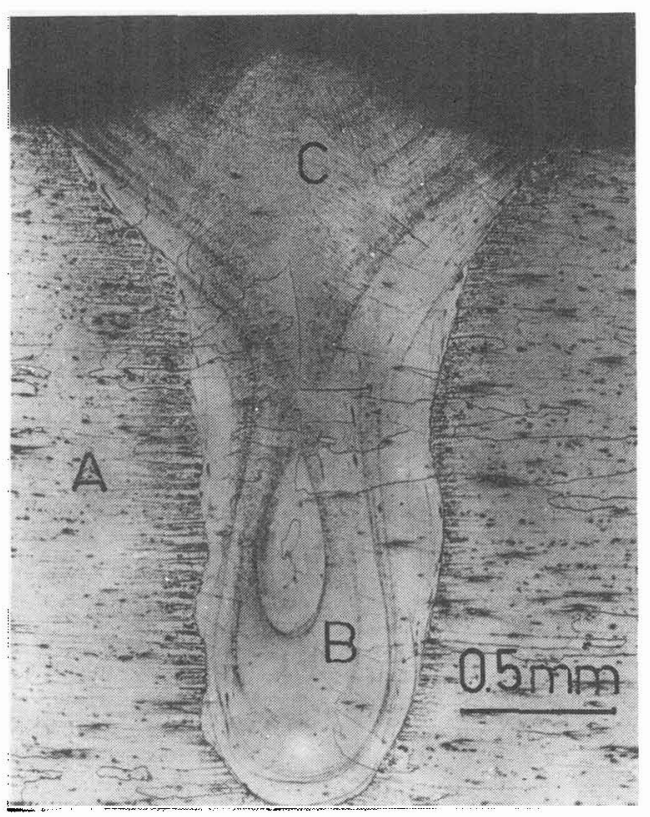

Fig. 2 Metallographic i mage of a transversal section of the irradiation track. 


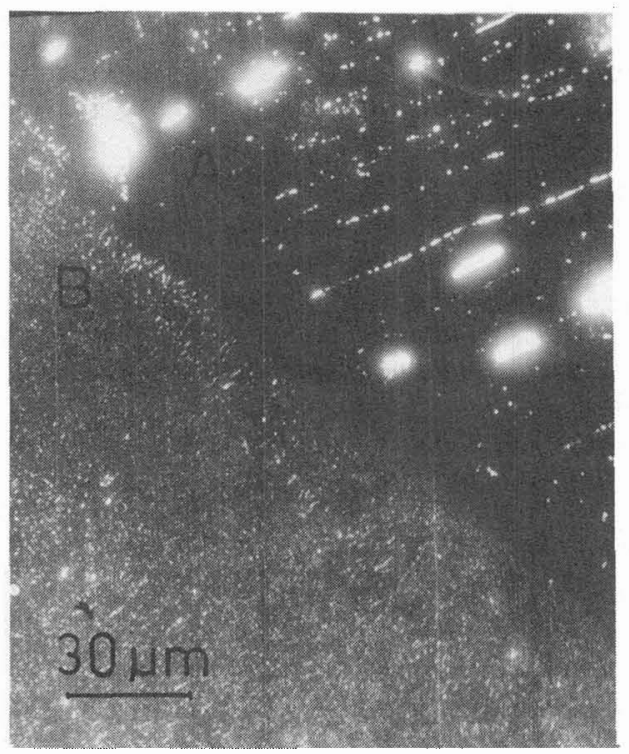

Fig. 3 SEM image of the interface between zone $A$ and zone $B$

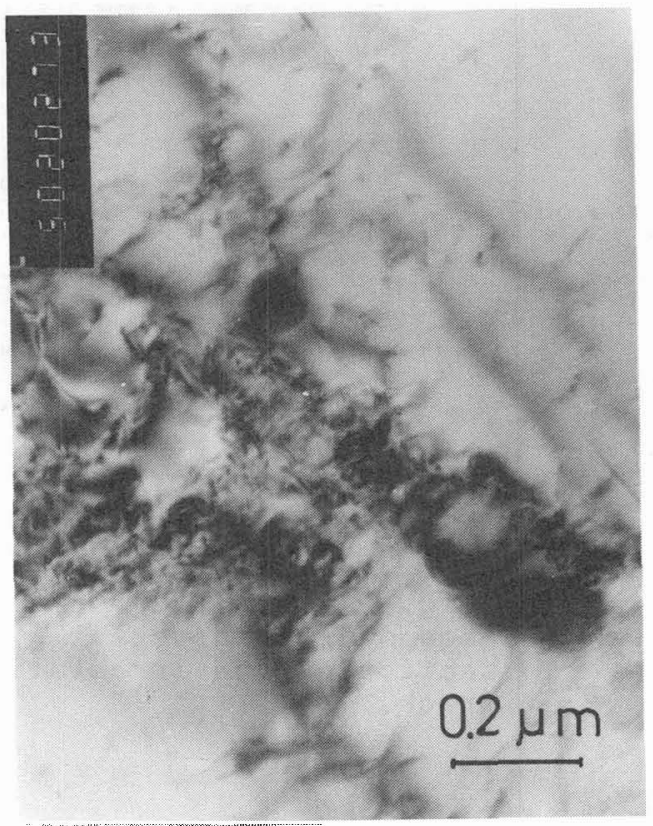

Fig.5 TEM image of the ture $\varepsilon$ - carbide

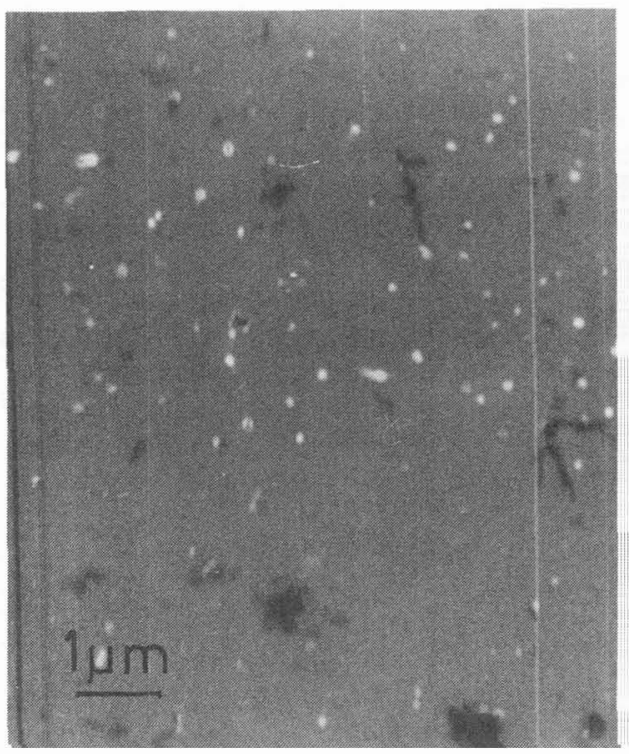

Fig. 4 SEM image of zone $B$

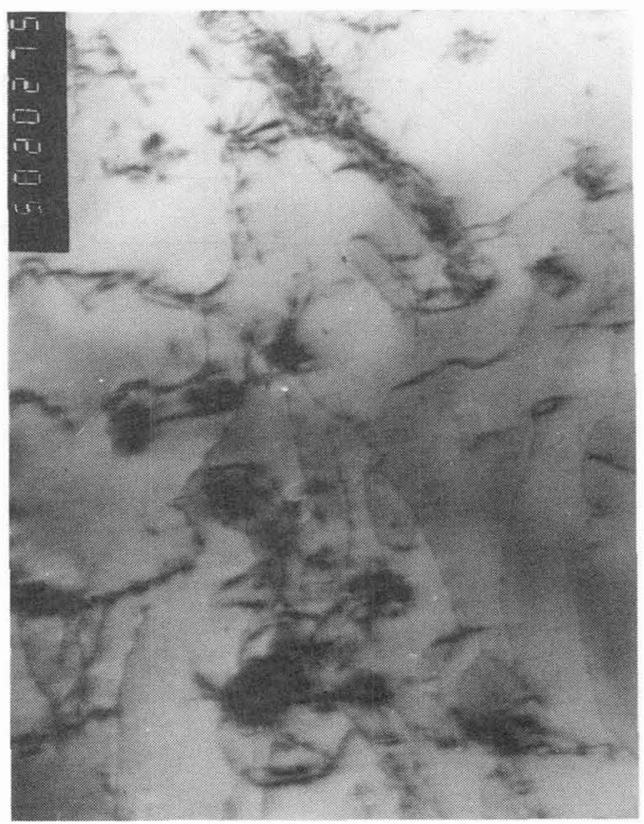

Fig.6 TEM image of small precipitates in the initial state of the precipitation process. 